\title{
Correction to: Parametric Investigation of a Rail Damper Design Based on a Lab-Scaled Model
}

\author{
Alireza Jahan Tigh Kuchak ${ }^{1} \cdot$ Dragan Marinkovic ${ }^{1} \cdot$ Manfred Zehn ${ }^{1}$
}

Published online: 19 June 2021

(c) The Author(s) 2021

\section{Correction to: Journal of Vibration Engineering \& Technologies (2021) 9:51-60 https://doi.org/10.1007/s42417-020-00209-2}

The article Parametric Investigation of a Rail Damper Design Based on a Lab-Scaled Model, written by Alireza Jahan Tigh Kuchak, Dragan Marinkovic and Manfred Zehn, was originally published Online First without Open Access. After publication in volume 9, issue 1, page 51-60 the author decided to opt for Open Choice and to make the article an Open Access publication. Therefore, the copyright of the article has been changed to ()$^{\circ}$ The Authors 2020 and the article is forthwith distributed under the terms of the Creative Commons Attribution4. 0 International License, which permits use, sharing, adaptation, distribution and reproduction in any medium or format, as long as you give appropriate credit to the original author(s) and the source, provide a link to the Creative Commons licence, and indicate if changes were made. The images or other third party material in this article are included in the article's Creative Commons licence, unless indicated otherwise in a credit line to the material. If material is not included in the article's Creative Commons licence and your intended use is not permitted by statutory regulation or exceeds the permitted use, you will need to obtain permission directly from the copyright holder. To view a copy of this licence, visit http://creativecommons.org/licenses/by/4.0.

The original article has been corrected.

Open Access This article is licensed under a Creative Commons Attribution 4.0 International License, which permits use, sharing, adaptation, distribution and reproduction in any medium or format, as long as you give appropriate credit to the original author(s) and the source, provide a link to the Creative Commons licence, and indicate if changes were made. The images or other third party material in this article are included in the article's Creative Commons licence, unless indicated otherwise in a credit line to the material. If material is not included in the article's Creative Commons licence and your intended use is not permitted by statutory regulation or exceeds the permitted use, you will need to obtain permission directly from the copyright holder. To view a copy of this licence, visit http://creativecommons.org/licenses/by/4.0/.

Publisher's Note Springer Nature remains neutral with regard to jurisdictional claims in published maps and institutional affiliations.

The original article can be found online at https://doi.org/10.1007/ s42417-020-00209-2.

Dragan Marinkovic

dragan.marinkovic@tu-berlin.de

Alireza Jahan Tigh Kuchak

alireza.jahantighkuchak@campus.tu-berlin.de

Manfred Zehn

manfred.zehn@tu-berlin.de

1 Department of Structural Analysis, Institute of Mechanics, Technical University Berlin, Str. d. 17. Juni 135,

10623 Berlin, Germany 